\title{
Automatic Cat Breeding and Drinking Equipment via Mobile Network Monitoring
}

\author{
Feranita \\ Electrical Engineering Department, \\ Universitas Riau \\ Pekanbaru, Indonesia \\ feranita@eng.unri.ac.id
}

\author{
*Ery Safrianti \\ Electrical Engineering Department, \\ Universitas Riau \\ Pekanbaru, Indonesia \\ esafrianti@eng.unri.ac.id
}

\author{
Yuli Sartika Tambunan \\ Electrical Engineering Department, \\ Universitas Riau \\ Pekanbaru, Indonesia \\ yulisartika@student.unri.ac.id
}

*corresponding author: ery safrianti, esafrianti@eng.unri.ac.id

\begin{abstract}
This study aims to design a feeding and drinking tool for pet cats automatically based on SIM900A GSM Module. Design using GSM SIM900A, Arduino, RTC, load cell and Direct Current (DC) pump. This tool can be controlled to feed and drink the cat automatically at a distance. The working system of the tool consists of load cell 1 , load cell 2 and water limit sensor which is an input result of measurement object which will be processed by Arduino. Load cell 1 is used for measuring cat body weight, load cell 2 serves to measure cat feed weight and water limit function to enable and disable direct current pump. The pump will pump water to fill the cat drinking container if the container is empty. Data received by Arduino will be processed when the Real Time Clock (RTC) indicates the schedule of the cat's feeder that has been set. Then the SIM900A GSM module will work sending short messages (SMS) to the mobile phone to inform the system has been working automatically feed the cat.
\end{abstract}

Keywords-Pet cats, Automatic feeding, SIM900A GSM module, RTC, DC pump.

\section{INTRODUCTION}

Research on Automatic Feeding and Drinking for Pet Cats on a scheduled basis using Microcontroller has been done by [1]. Atmega16 Auto-feeding and Atmega16 AutoDrinking Equipment [2] and Design of Microcontroller Based Automatic Feeding System by [3]. Through the background of existing researches, innovations will be made in this research to make it easier for pet owners to care for their pets either directly or indirectly. What distinguishes it from existing research is the use of two load cells as a detector of the west body weight of the cat and the weight of cat food in the container. This tool is also equipped with automatic actuator drinking using DC pump. Another advantage is the notification or monitoring via cellular network.

\section{EQUIPMENTS}

\section{A. SIM900A GSM Module}

SIM900 GSM / GPRS module [4] is the part that serves to communicate between main monitor with mobile phone. AT Command is an instruction that GSM / CDMA modem can provide to send and receive GSM / GPRS based data, or send and receive SMS (Short Message Service). Figure 1 shows the SIM900A board shape.

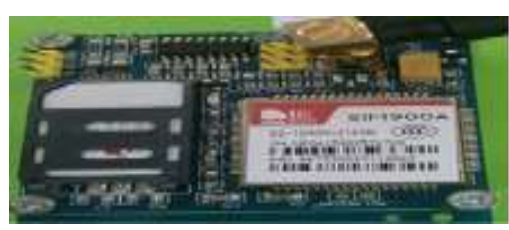

Figure 1: Board SIM900A.

\section{B. Arduino UNO}

Arduino UNO is a microcontroller board based on ATmega328. The Arduino UNO has 14 digital input / output pins ( 6 of which can be used as PWM output), 6 analog inputs, a $16 \mathrm{MHz}$ Crystal oscillator, a USB connection, a power jack, an ICSP header, and a reset button.

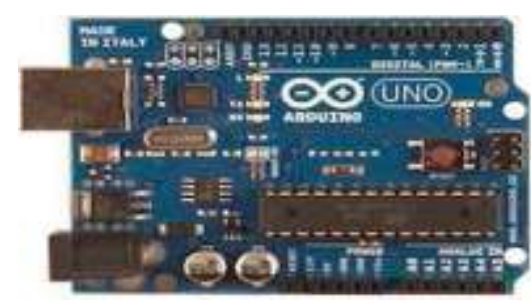

Figure 2: Arduino display

The Arduino UNO contains everything needed to support the microcontroller, so it is easy to connect it to a computer 
with a USB cable or supply it with an AC adapter to DC or using a battery. Figure 2 shows Arduino Display.

\section{Relay}

Relays are electrically operated switches. It is an electromechanical component consisting of 2 main parts, namely electromagnet (coil) and mechanical (switch switch / switch). Relays work on the principle of a switch so that a small electric current (low power) can conduct higher voltage electricity.

\section{DC Motor}

An electric motor converts electrical energy into mechanical energy. Most electric motors operate through the interaction of the magnetic field and the current carrying conductor to produce power, even though the electrostatic motor uses an electrostatic force. The reverse process, generating electrical energy from mechanical energy, is performed by generators such as alternators, or dynamos. Many types of electric motors can be run as generators, and vice versa. For example, a generator / starter for a gas turbine, or traction motor used for a vehicle, often performs both tasks. Electric motors and generators are often referred to as electric machines. Figure 3 is a DC motor image to be used on a cat feeding device. The motor has a series of gear that is useful to propel a cat feeding container.

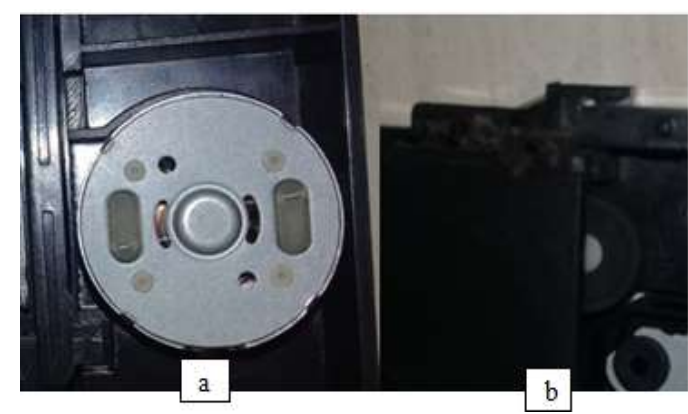

Figure 3: DC motor (a) front view; (b) back view.

\section{E. Load Cell Sensor}

Sensor Load cell is a sensor designed to detect the pressure or weight of a load, the load cell sensor is generally used as a major component on the digital scales. Another application on weight measurement that serves to measure weight. The measurements performed by the load cell use the pressure principle.

\section{F. Hx711 Module}

Hx711 is a weighing module, has a working principle of converting measurable changes in resistance changes and converting them into voltage quantities through existing circuits. This module has a simple structure, easy to use, stable and reliable results, has high sensitivity, and is able to measure changes quickly.

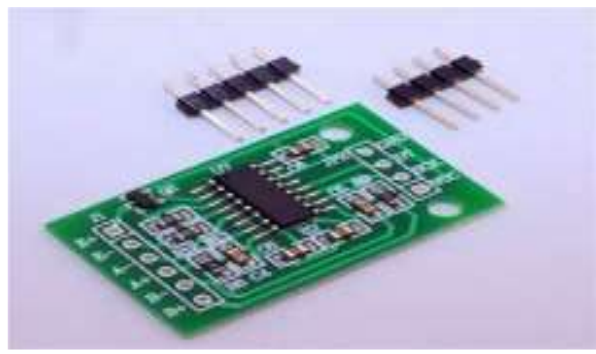

Figure 5: Hx711 module.

\section{RESEARCH METHODOLOGY}

Diagram block of cat breeding and drinking equipment based on SIMM900A GSM Module shown in figure 6 .

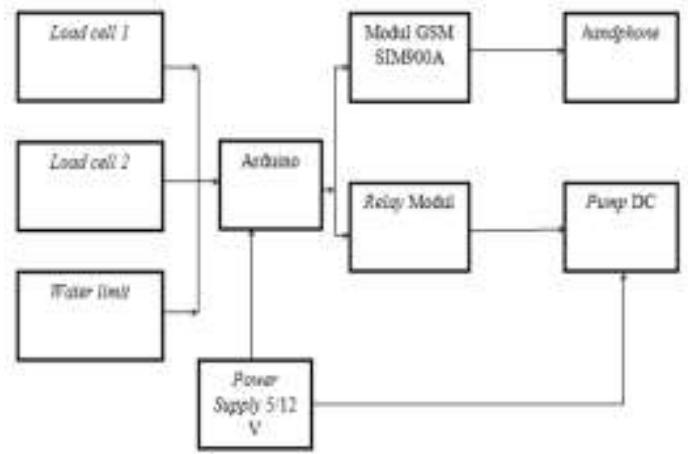

Figure 6: General block diagram of the equipment.

Figure 6 shows the work system of the designed device in which load cell 1 , load cell 2 and the water limit sensor are an input of the object measurements to be processed by the Arduino. Load cell 1 is designed to measure cat's weight, load cell 2 serves to measure the weight of feeding the cat and water limit to enable and disable the DC pump. The data received by Arduino will be processed when RTC time indicates cat feeding schedule that has been set then GSM SIM900A module will work sending SMS to mobile phone when system has been working automatically feed cat.

\section{A. Power Supply Design Using Arduino}

Power Supply serves to supply 5 Vdc power to Arduino, using $2 \mathrm{~A}$ transformer to lower 220 Vac voltage rectified by diode.

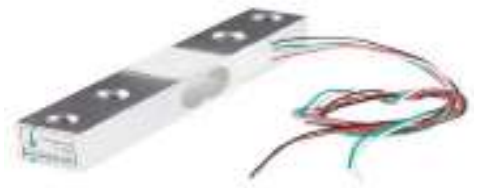




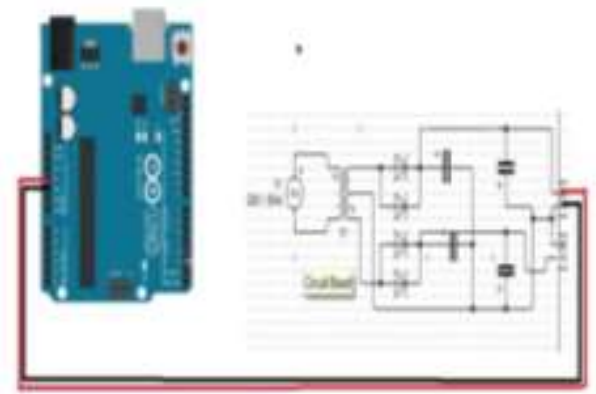

Figure 7: Arduino power supply circuit.

\section{B. Load Cell 1 Design Using Arduino}

This series of 1 cell load sensors serves to display the weight of a cat on a serial monitor on a laptop or computer when a cat is weighed before entering the cage. In this design, pin 12 and pin 13 of, the are connected to DAT and SCK on the ADC load cell as shown in Figure 8.

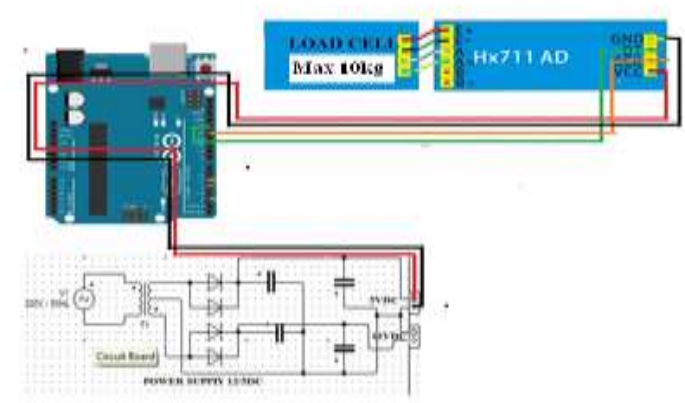

Figure 8: Series with load cell sensor 1.

\section{Load Cell 2 Design Using}

This series of load cell 2 sensors serves to display the weight of cat food that falls on the cat feed container as programmed. In this design, pin 4 and pin 5 of the Arduino connected to DAT and SCK on the ADC load cell as shown in Figure 9.

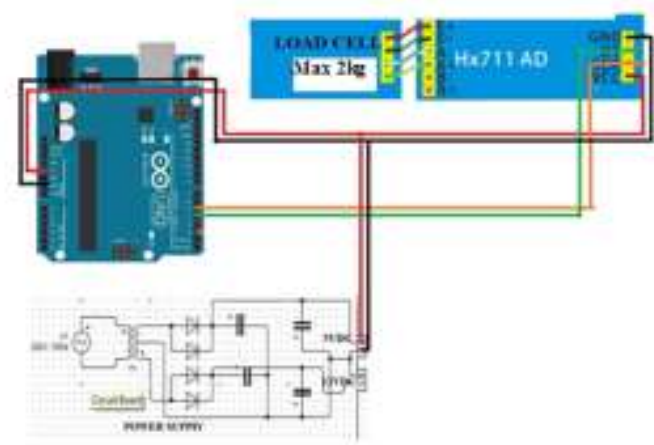

Figure 9: Arduino series with load cell sensor 2.

\section{GSM 900A Module Design Using Arduino}

This series serves to instruct the GSM module to send an SMS to the owner that the feed has been given. The following picture of the communication circuit between Arduino and GSM module.

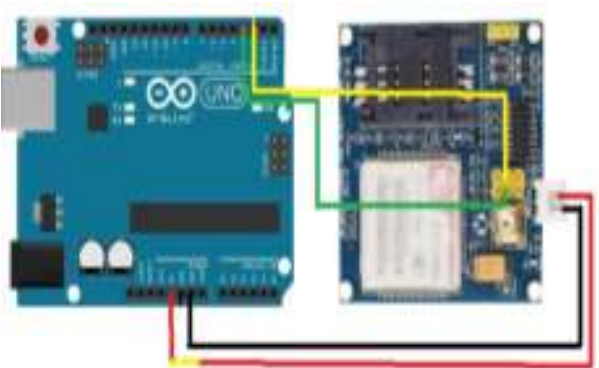

Figure 10: Arduino series with GSM 900A module.

\section{E. DC Motor Design Using Arduino}

This design uses Arduino and Motor drivers to drive DC motor, Arduino is used to control the output of DC motor rotation which then is controlled by motor driver. DC motors serve as opening and closing valves for cat food supply containers.

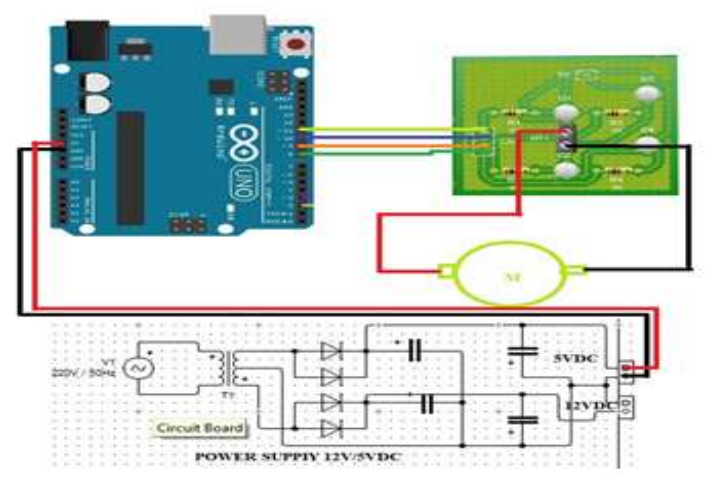

Figure 11: Arduino series with DC motor.

\section{F. RTC Design Using Arduino}

RTC circuit uses IC DS1302 as the data management center for hours, minutes, seconds, date, month and year.

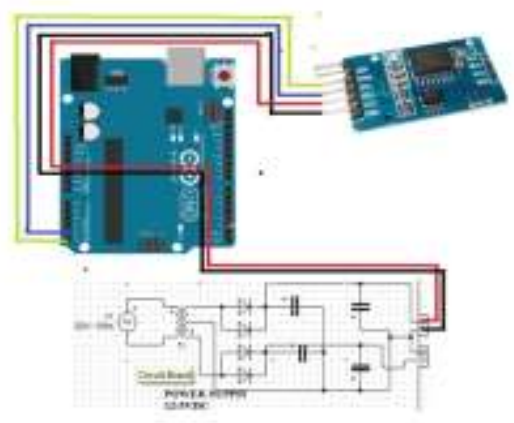

Figure 12: RTC circuit using Arduino.

\section{G. Relay Design with Arduino}

Relay serves as a water sensor on drinking cats. Here is a series of relay design with Arduino. 


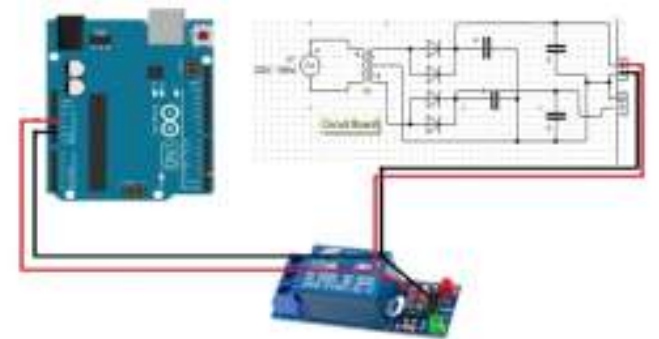

Figure 13: Arduino series with relay.

\section{RESULTS AND DISCUSSION}

In performing these measurements, the cat food given and tested is the "Whiskas" brand and the test is performed according to the dosage of cat feed according to the "Whiskas" table dosage indicated on the "Whiskas" packaging.

Table 1: Comparison of cat lives to cat weight according to "Whiskas"

\begin{tabular}{|c|c|}
\hline Cat Weight $(\mathrm{kg})$ & Number of Doses / Day (gr) \\
\hline $1-2$ & $15-35$ \\
\hline $2-3$ & $35-50$ \\
\hline $3-4$ & $50-65$ \\
\hline $4-5$ & $65-85$ \\
\hline
\end{tabular}

Table 2: Test results cat (Weight 2-3 kg) feeding schedule

\begin{tabular}{|c|c|c|c|c|c|}
\hline Schedule & $\begin{array}{c}\text { Time } \\
\text { (WIB) }\end{array}$ & $\begin{array}{c}\text { Cat } \\
\text { Weight } \\
(\mathrm{gr})\end{array}$ & $\begin{array}{c}\text { Weight } \\
\text { of Feed } \\
\text { Released } \\
(\mathrm{gr})\end{array}$ & $\begin{array}{c}\text { SMS } \\
\text { from } \\
\text { SIM900A }\end{array}$ & $\begin{array}{c}\text { Dropped } \\
\text { Food } \\
\text { Amount } \\
(\mathrm{gr})\end{array}$ \\
\hline Morning & $08: 00$ & 2677.1 & 47.5 & give meal & 51.7 \\
\hline Noon & $13: 00$ & 2677.1 & 41.7 & give meal & 50.0 \\
\hline Night & $18: 00$ & 2677.1 & 47.6 & give meal & 51.8 \\
\hline
\end{tabular}

Table 3: Test results cat (Weight 3-4 kg) feeding schedule

\begin{tabular}{|c|c|c|c|c|c|}
\hline Schedule & $\begin{array}{c}\text { Time } \\
(\text { WIB })\end{array}$ & $\begin{array}{c}\text { Cat } \\
\text { Weight } \\
(\mathrm{gr})\end{array}$ & $\begin{array}{c}\text { Weight } \\
\text { of Feed } \\
\text { Released } \\
(\mathrm{gr})\end{array}$ & $\begin{array}{c}\text { SMS } \\
\text { from } \\
\text { SIM900A }\end{array}$ & $\begin{array}{c}\text { Dropped } \\
\text { Food } \\
\text { Amount } \\
(\mathrm{gr})\end{array}$ \\
\hline Morning & $08: 00$ & 3194.8 & 51.0 & success & 52.7 \\
\hline Noon & $13: 00$ & 3194.8 & 65.3 & success & 57.7 \\
\hline Night & $18: 00$ & 3194.8 & 63.5 & success & 65.2 \\
\hline
\end{tabular}

Table 4: Test results cat (Weight 4-5 kg) feeding schedule

\begin{tabular}{|c|c|c|c|c|c|}
\hline Schedule & $\begin{array}{c}\text { Time } \\
(\text { WIB })\end{array}$ & $\begin{array}{c}\text { Cat } \\
\text { Weight } \\
(\mathrm{gr})\end{array}$ & $\begin{array}{c}\text { Weight } \\
\text { of Feed } \\
\text { Released } \\
(\mathrm{gr})\end{array}$ & $\begin{array}{c}\text { SMS } \\
\text { from } \\
\text { SIM900A }\end{array}$ & $\begin{array}{c}\text { Dropped } \\
\text { Food } \\
\text { Amount } \\
(\mathrm{gr})\end{array}$ \\
\hline Morning & $08: 00$ & 4507.2 & 78.8 & $\begin{array}{c}\text { Beri } \\
\text { Makan } \\
\text { Sukses }\end{array}$ & 79.8 \\
\hline Noon & $13: 00$ & 4507.2 & 78.8 & $\begin{array}{c}\text { Beri } \\
\text { Makan } \\
\text { Sukses }\end{array}$ & 80.0 \\
\hline Night & $18: 00$ & 4507.2 & 79.2 & $\begin{array}{c}\text { Beri } \\
\text { Makan } \\
\text { Sukses }\end{array}$ & 81.2 \\
\hline
\end{tabular}

\section{A. Data Analysis}

After the test by feeding 3 times a day with a predetermined time, then obtained the average weight of the meal issued in one day as follows:

$$
\begin{gathered}
\text { Result }=\frac{\text { WFmorning }+ \text { WFnoon }+ \text { WFnight }}{3} \\
\text { Result }=\frac{47.5+41.6+47.6}{3}=45.66
\end{gathered}
$$

Testing has been done for the whole tool. The following is an evaluation table of tools testing results:

\begin{tabular}{|c|c|c|}
\hline Action performed & Running process & Result \\
\hline $\begin{array}{l}\text { Providing current } \\
\text { supply to all circuits } \\
\text { such as: Arduino, } \\
\text { relay, RTC, load cell, } \\
\text { GSM 900A Module. }\end{array}$ & $\begin{array}{l}\text { The circuit receives the } \\
\text { power supply according to } \\
\text { the required specifications. }\end{array}$ & $\begin{array}{c}\text { Worked } \\
\text { well }\end{array}$ \\
\hline $\begin{array}{l}\text { Load cell } 1 \text { read the } \\
\text { weight of the cat. }\end{array}$ & $\begin{array}{l}\text { The arduino receives data } \\
\text { from load cell } 1 \text { according } \\
\text { to the weight of the cat. }\end{array}$ & $\begin{array}{c}\text { Worked } \\
\text { well }\end{array}$ \\
\hline $\begin{array}{l}\text { Load cell } 2 \text { reads the } \\
\text { weight of cat food } \\
\text { from the container. }\end{array}$ & $\begin{array}{c}\text { Arduino receives data from } \\
\text { load cell } 2 \text { according to the } \\
\text { size of cat food that has } \\
\text { been loaded }\end{array}$ & $\begin{array}{c}\text { Worked } \\
\text { well }\end{array}$ \\
\hline $\begin{array}{c}\text { Relay activate and } \\
\text { deactivate DC pump. }\end{array}$ & $\begin{array}{c}\text { The DC pump is active } \\
\text { when logic } 1 \text { and off when } \\
\text { logic } 0 .\end{array}$ & $\begin{array}{c}\text { Worked } \\
\text { well }\end{array}$ \\
\hline $\begin{array}{l}\text { RTC reads the time } \\
\text { according to the time } \\
\text { set. }\end{array}$ & $\begin{array}{l}\text { Time is displayed on the } \\
\text { monitor series according to } \\
\text { the digital clock. }\end{array}$ & $\begin{array}{c}\text { Worked } \\
\text { well }\end{array}$ \\
\hline $\begin{array}{l}\text { GSM SIM 900A } \\
\text { module sends SMS to } \\
\text { mobile phone. }\end{array}$ & $\begin{array}{l}\text { Handphone received SMS : } \\
\text { "Beri Makan sukses" from } \\
\text { SIM900A GSM Module. }\end{array}$ & $\begin{array}{c}\text { Worked } \\
\text { well }\end{array}$ \\
\hline $\begin{array}{l}\text { Arduino controls } \\
\text { input and output data. }\end{array}$ & $\begin{array}{l}\text { The system works and } \\
\text { complies with programmed } \\
\text { commands. }\end{array}$ & $\begin{array}{c}\text { Worked } \\
\text { well }\end{array}$ \\
\hline
\end{tabular}

Table 5: Evaluation of test results 


\section{CONCLUSION}

From the results of tests that have been done can be concluded that: automatic cat breeding and drinking equipment using GSM Module SIM900A and Arduino, designed using two load cell that serves to weigh the weight of cats and the weight of cat food. The tool is equipped with RTC to calculate the time according to the digital clock. The amount of food expended is measured by the weight of the cat and adjusted to the dosage of the Whiskas brand. The test results were done by measuring the weight of the object (cat) that is $2677.1 \mathrm{gr}$ and produce average weight of food that came out as much as $45,66 \mathrm{Gr}$. The prescribed cat feeding schedule is 3 times, at $08.00 \mathrm{AM}$, at $01.00 \mathrm{PM}$ for lunch and 6.00 PM for dinner.

\section{REFERENCES}

[1] Ayunita, Rizky, "Automatic scheduled feeding and caterpillar kit form microcontroller", Universitas Gadjah Mada, Yogyakarta, 2016.

[2] Mardiyansyah, "Automotive System Design of Microcontroller Based Automatic Feeding Equipment", State Polytechnic of Padang, 2016.

[3] Husada, Tosa Anhar, "Atmega16 Auto Based Tablet and Atomizer Kit” Universitas Gadjah Mada, Yogyakarta, 2014.

[4] Barir, Syifaul. Ary, Mujadin, Anwar, "Universal Control Using GSM Module Sony Ericsson GM4 Jakarta", National Conference and Gathering of Information and Communication Technology for Indonesia, 